Historic, Archive Document

Do not assume content reflects current scientific knowledge, policies, or practices. 

A. B. KUNDERD (K)

Ruffled Cream and Pink

ALTAMYRA (D) Large Lilac

ANNA EBERIUS (D) Popular Velvety Purple

ARLON (K) Light Salmon Prim

AVIATRIX (Kemp) Shrimp Pink

BEATRIZ MICHELENA Peach Red Orange $\begin{array}{cr}\text { BENGAL TIGER (Pratt) } & 10 \\ \text { Brilliant Mottled Red } & 100\end{array}$

BERNARD SHAW (D)

BLACK PANSY (K) Rich Dark Red

BLASCO IBANEZ (D) Deep Dahlia Purple

BREAK O' DAY (Bill). Rare Early Pink

BYRON L. SMITH (K) Lavender

CORRI (Eu)

CRIMSON GLOW (Betscher).................... 10 Glowing Crimson 100

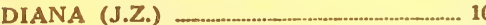
Fine Red

DIENER'S AM. BEAUTY (D) ................ 10 American Beauty Rose

DON JUAN (K)

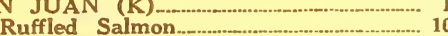

DR. F. E. BENNETT (D) _............. 1 "House Afire" Red 10 Gorgeous Display

DR. NEELEY (K) White, Slender Spike

DR. W. VAN FLEET (K) ................... 10 Extra Early Rose Pink

EXCELLO (K). Salmo (K)

E. G. HILL (K)

E. J. SHAYLOR (K) Ruffled Rose Pink

ELAINE (Bill) Lily White

ELF (D) Fine Florists ${ }^{\circ}$ White

ELIZABETH TABOR (Hinkle) Early Large Pink $\begin{array}{lr}\text { White, With Rich Pink Throat } & 10 \\ \text { ORA } & 100\end{array}$

ENIGMA (K) Oddly Striped

EVELYN KIRTLAND (Austin) ............ 10 Beautiful Pink 100

FERN KYLE (K)

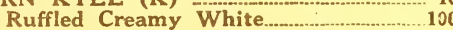

FONTAINE (C) Dainty Creamy White 100

GERTRUDE ERREY (Australia)............. Very Beautiful Pink 10

FASTIDIOUS (Bill)

GIANT NYMPH (C)

GLADIS PLATH (D) Mallow Purple

100 10 10 10 10 1 10 100 1

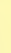
10 10

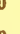

\section{SPRING 1926}

No. 1 No. 2 No. 3

$1 \frac{1 / 4}{1}-1 \frac{1}{3} \quad 1-11 / 4$

.

10

\section{1}

1

10

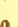

10

10

10

100

1

1

$\begin{array}{ccc}\ldots \ldots . . & \$ .80 & \$ .50 \\ \ldots \ldots & \ldots \ldots . . & \ldots\end{array}$

\begin{tabular}{|c|c|c|}
\hline ...n.... & 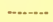 & …....... \\
\hline .... & .55 & .40 \\
\hline 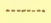 & ....... & …….. \\
\hline .50 & .40 & .30 \\
\hline 3.75 & 3.00 & 2.25 \\
\hline .35 & .30 & .25 \\
\hline 1.75 & 1.50 & 1.25 \\
\hline
\end{tabular}$$
.80
$$$$
\begin{array}{rr}
.80 & .60 \\
4.00 & 5.25 \\
\hdashline . .50
\end{array}
$$$$
\text { …..... }
$$$$
2.50
$$$$
12.50
$$$$
15.00
$$$$
135.00
$$$$
.60 \quad .50
$$$$
1.00 \quad .90
$$$$
.60 \quad .50
$$$$
\begin{aligned}
& .00 \quad 4.00 \\
& \hline
\end{aligned}
$$$$
.65
$$$$
1.25
$$$$
\text { ........ }
$$$$
\begin{array}{r}
.25 \\
1.90
\end{array}
$$$$
.90
$$
10 10

10
10 10$$
8.50
$$$$
\text { ….... } \quad 3.00
$$

No. 4

$3 / 8-1 \quad 1 / 20.5$ No. 6

$\$ .35 \$ \$ .25 \quad \$ .20$

2.75

.45

4.05

.30
2.25

.25

1.75

.20
1.00

1.00

.35

2.75

2.50

.70
6.00

6.50

9.00

81.00

.30

2.25

.70

.25

.35

3.00

.45

4.00

.15
1.20

.45

4.00
36.00

2.00

2.00

.40
3.75

.50

.50

.60

.25

.45

4.05

…... $\quad$-.......

.35

.25

.20

1.10

.35

.50

$1.75 \quad 1.00$

$.35 \quad .25$

3.15

.20
1.25

.20
1.25

.15
.75

$\begin{array}{lr} & 1.35 \\ \ldots . . . . . & 12.15\end{array}$

2.00

1.25

2.00

1.50

5.00

.50
4.00

.75

7.00

63.00

.20

1.25

.15

1.25

2.00

3.00

.10

.35

3.00
27.00

$\quad 18.00$

……. $\quad .45$

.30

2.75

.35

.45

.20

.35

3.15

.25

1.75

.15
.80

.25
2.00

.10

.75

.30

$6.00 \quad 5.00 \quad 4.00$

2.00

18.00

1.75

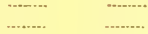

$5.00 \quad 4.25$

3.50

.55

$.70 \quad .65$

.90 
GLENDALE (Davis) Tall Purple

3.0

GLORIANA (Betscher) 1

GOLD (Decorah) Fine Florists' Yellow

GOLDEN TINGE (K) Golden Orange Prim 10 GOOD GRACIOUS (M) 10 GOOD GRACIOUS (M) Red (K) 1

HALCYON (Bill) 10

HAWAII (D) Rose Pink, Dark Blotch

1.10

…...

…...

.90
8.00

2.60

2.10

$\ldots$

.95

$+$

.65

.60

5.50

5.00

.70

6.00

HENRY FORD (D) Vigorous Purple

HERADA (Austin) Vigorous Mauve

HIGH NOON (M)

INDIAN SUMMER (K) Glistening Pink

J. A. CARBONE (D) Fine Iridescent Orange Stands Heat Extra Well

JEWELL (C.Z.)

Pink, with Yellow Throat

JOHN E. PEABODY (M)

JOHN T. PIRIE (K) Mahogany Brown

JOSEPH FIELD (D)

JUNO (C)

KATHARINE F. HESS (D) Geranium Pink

LEOTA (C) Pink

10 1 .................

.65

5.50

.40

.50

.50

4.50

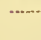

$\ldots$

.65

.50

2.50

2.50

.90

1.25

…....

1.00

1.40

MADISON COOPER (K) Purplish Satiny Red MARIE KUNDERD (K)
Early White, Pointed Petals

MARSHAL FOCH (K) _..................... 10 Beautiful Light Salmon Pink 100

MARY PICKFORD (K) …...................... 10 White

MASTERPIECE (K)

100

MAJESTIC (Hopman)

Orange Salmon -

MING TOY (K) ……................................ Buff Yellow

MINUET (C) Most Beautiful Lavender.

MISS SPOKANE (K) Ruffled Orange Salmon

MR. W. H. PHIPPS (D) ................... 1 Iridescent Pink, Many Open
Heads List in Symposium Vote 100 MRS. F. C. PETERS (Fischer) ........... 10 Tall Lavender

MRS. H. E. BOTHIN (D) Creamy Pink, Wayy Edges

MRS. J. C. GROSSMAN (G) ......... Deep Salmon Primulinus................... 10

MARIETTA (M) ……………. Extra Fine Salmon …ㄴ..………..... 10 \begin{tabular}{c|c} 
MRS. JOHN R. WALSH (D) & 10 \\
Ruffled Flesh Pink & 100
\end{tabular}

MRS. JOHN S. WOOD (M)

MRS. J. K. ARMSBY (D)

Fine Coral Pink

MRS. FRANK PENDLETON (K) ..... 10

MRS. LEON DOUGLAS (D) ................... 10 Extra Fine Salmon Pink

$-2.50$

$.55 \quad .45$

$.50 \quad .40$

4.50

3.50

4.00

.60

.50

........

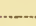

.55
5.00

.35

.45

.45
3.50

30.00

.50

.55

.45

2.10

.80

1.00

…......................

.50

.85

.60

.30

3.00

24.00

.40

.45

7.00

15.00

1.50

1.25

.60

$\begin{array}{rr}.60 & .45 \\ 5.00 & 4.00\end{array}$

.90

7.50

.80

6.50

$100.00 \quad 80.00$

.70

5.00

60.00

$1.20-1.00$

$10.00 \quad 8.00$

.85

.70

$\begin{array}{rr}.35 & .30 \\ & 1.90\end{array}$

.25
1.50

7.50 $\begin{array}{lll}3 / 4-1 & \text { No. } 5 & \text { No. } 6 \\ 1 / 2-3 / 4 & 1 / 2 \text {-less }\end{array}$

BULBLETS

Per

$\begin{array}{r}100 \\ 1000 \\ \hline\end{array}$

$10 \quad 2.00$

$100 \quad .65$

100

$1000 \quad 1.50$

6.00

4.50

3.00

.60

.55

6.50

.20

.15

2.00

.35

.30

$.30 \quad .20$

2.50

1.50

.15

$\begin{array}{lll}3.50 & 3.00 & 2.50\end{array}$

.40

.30

2.50

$\begin{array}{lll}3.00 & 2.00 & 1.00\end{array}$

.45

3.50

.35
2.50

.25

…................

.25

.20

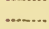

.15

$\begin{array}{rr}.30 & .20 \\ 1.50 \quad 1.00\end{array}$

.10
.80

$.30 \quad .20$

2.00

1.50

.30
2.75

.35

1.75

.35

3.15

1.20

.60

.70

6.50

.40
3.50

.45

.65

5.50

1.00

9.00

.45
4.00

.35

........

$\begin{array}{rr}.35 & .25 \\ 3.00 & 2.00\end{array}$

.60

3.25

45.00

$\begin{array}{rrr}.80 & .60 & .40 \\ 6.00 & 4.00 & 3.00\end{array}$

$.50 \quad .35$

4.50

40.00

3.00
25.00

$.65 \quad .50$

4.00

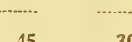

$\begin{array}{rr}.45 & .30 \\ 3.75 & 2.75\end{array}$

.25

2.00

.15

1.00

.20

1.10

.15
.90

.65
5.50

.45
3.50

Identically same as Mrs. Leon Douglas

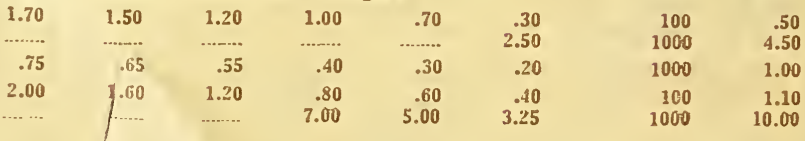




\title{
THE OREGON GIANTS FINEST GIANT RUFFLED PANSIES
}

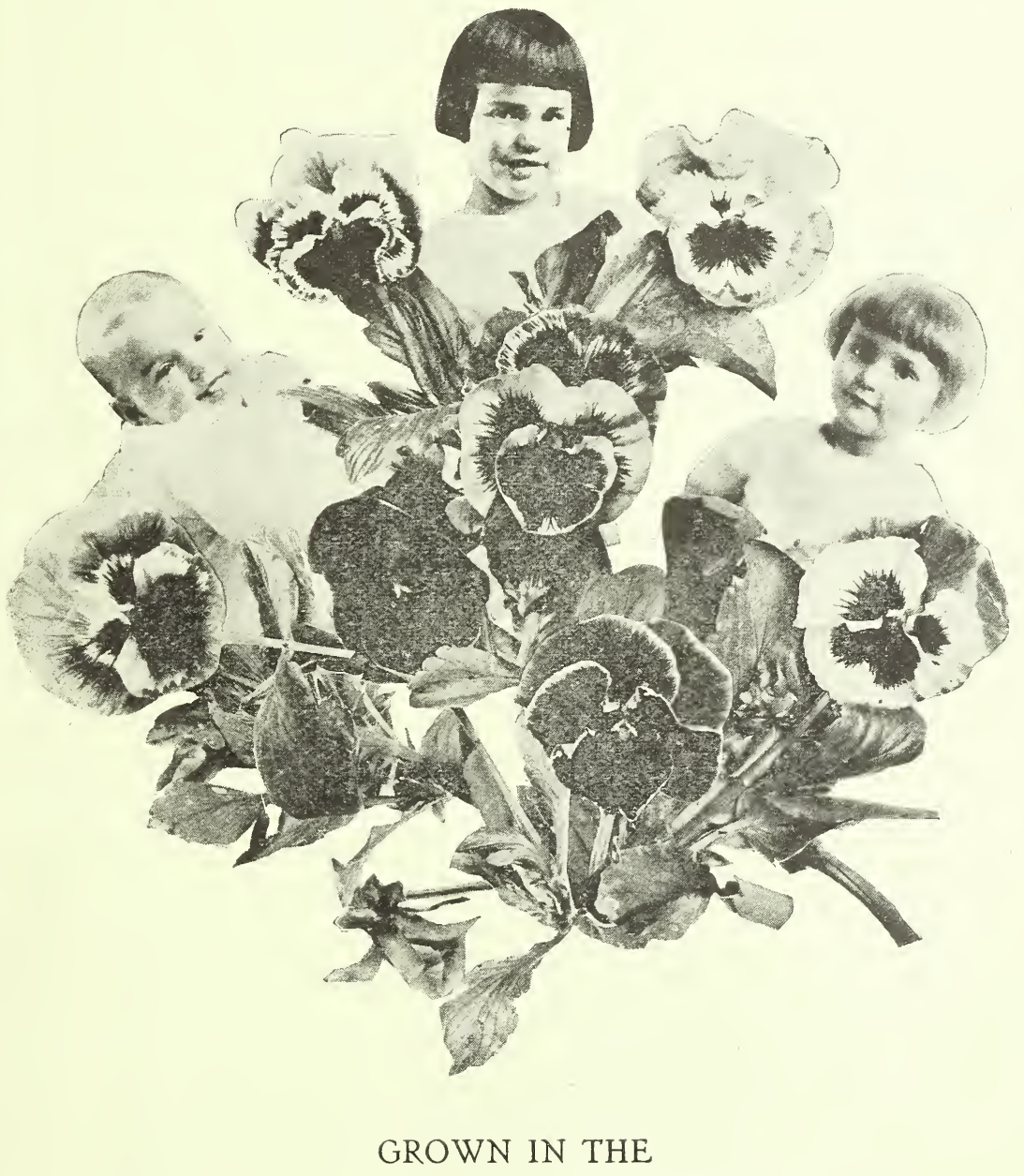

\author{
MERTON G. ELLIS TEST GARDENS \\ CANBY, OREGON
}




\section{Oregon Giant Pansy Seed FINEST FLORISTS' MIXTURE}

1,000 Seeds $\$ 1.00$

Trial Packet of 300 Seeds $35 c$ (No more than ten packets to one customer until after Aug. I5ih)

After September 1st-1/2 ounce. $\$ 5.00$

(Anyone wishing to plant seed in large quantities carly in the summer should order seed in the Fall for the following season. Many of our customers do this and report $100 \%$ germination.)

In some climates, it is desirable to plant seed in mid or late summer, while in other parts of the country, it is equally satisfactory to wait till early September, or even October.

Our fresh seed is not produced in large quantities till mid-summer, and because of the ever increasing demand, it is impossible to fill all our orders as early as we would like. Therefore, customers who must have their seed sent them before August 15th will please add 25\% to the list price. For instance: one packet (1,000 seeds) Finest Florists' Mixture will be $\$ 1.25$ before August 15 th.

It is our intention to fill most of our orders between August I5th and August 20th. Any customers who request that their seed be mailed after August zoth will receive $25 \%$ more in seed count. A great many of the a'ery best Pansies producc scarcely any seed till quite late, so the late orders are filled with seeds of extra quality.

All of our seed-plants are very carefully selected each year from among thousands, only the very largest and best being allowed to remain in the seed-beds. It has been our custon to then select the very best of these and stake them, saving the seed from them for an Extra Choice Mixture. From now on we intend to list only the Finest Florists' Mixture and the seed from the extra choice plants will go into the "Finest Florists' Mixture." Therefore, those who have used this Mixture may expect even more pleasing results than heretofore.

We are discontinuing listing the separate colors. We will grow them separately, as hefore, so there will ie the same distinction of color.

TERMS:-Please send remittance with order to:--

\section{CMRS. MERTON G. ELLIS}

CANBY, OREGON

(Visitors are welcome at our gardens. No business transacted on Sundays.) 


\section{WORTHWHILE EXPERIMENTS.}

A paragraph from a letter to us dated January 20, 1926, from an Instructor in the Research Department of the New York State Agricultural Experiment Station:

"I note that in the A. G. S. Bulletin there is always a great cry about buying bulbs from "cut rate" dealers. This wail emanates from a few sore heads who will not make the effort to grow glads by the scheme which you have worked out to increase the bulbiet yield and to make them germinate. We have used your method for 2 years and while we cannot equal your yields on certain varieties, I am satisfied that the bulblet yield by your method is fully 100-200 \% greater than by the style of propagation usually found among growers of this section and the bulblet germination greatly increased. If these price boosters would make the effort to grow their glads right I am satisied they could compete with your prices and some others and still make a large profit on their investment. I don't want to make any enemies among bulb growers, but if the hue and cry about cut rate dealers can't be stopped before long, some of us Experiment Station boys who are in the front of the procession will hive to take a hand by telling the public the facts. The public do not deserve to be gouged on prices just because a grower is ignorant or lazy. Your method involves a lot of back-aching work, but it brings results, as our experience testifies."

An Eastern grower writes us that he had been told Oregon Bulbs are no good. Thinking this was through jealousy, he tried an experiment. He bought bulbs from all over the country. He sent us an order without saying what he had in mind. The order was filled from our regular stock. He planted them all sicie by side and says our Oregon Bulbs beats them all. This shows our methods do not injure the bulbs, but that they are filled with pep and that "Oregon Bulbs are Best."'

Our methods are described in "Making Them Grow." This is a treatise on the rapid propagation of the new and high priced Gladioli. It is not a large book but many say it is worth hundreds of dollars. Price 3.50 postpaid.

THE MRRTON G. ELLIS TEST GARDENS, CANBY, OREGON. 



\section{WHAT OTHERS THINK OF THE OREGON GIANTS}

"For years I have been trying to procure a Pansy that excelled both in coloi and size, and have found this in the Oregon Giants. I received some of your seed and have had exceptional success. The pale blues were wonderful."

H. C. WEINMANN, Indianola, Iowa.

"I am sending you an order for Pansy Seed to plant this Fall. Two years ago I planted your seeds and had the most wonderful pansies I have ever seen. We measured some that were $31 / 4$ inches, and all shades and colors. People came for many miles to see them, and I sold quite a lot of plants and gave away a great many blossoms." MRS. G. V. ROBINSON, Rough \& Ready, Calif.

"I have never seen such Pansies as grew from your seed. The whole neighborhood has gone wild over the Oregon Giants."

MRS. W. F. WILT, Kearneystille, W. Va.

"We saw some of your wonderful Pansies at San Dimas, and want some, too." MRS. MAYBELL WATSON, Sta. T, Los Angeles, Calif.

"I was so well pleased with the Pansies produced from the seed purchased from you last year that I am enclosing herewith money order for the same quantity of the Oregon Giants. I never saw such size of bloom or colors."

F. C. STONE, Prescott, Ont., Canada.

"Please send me your package of Finest Florists" Mixture Pansy Seed as soon as possible. The seed I got last year produced some wonderful blooms. Everyone says, 'What lovely pansies.' My pansy bed at present is just full of blooms of wonderful size and color, and it has been so all summer. I am certainly delighted with them."

MRS. E. WHITEHEAD, Gen. Del., Woodstock, Ont., Canada.

"I saw some of your prize Pansies at the Flower Show here last year and want to add them to my much cherished garden."

MRS. JAS. R. RAVIN, 126 Wellington St. N., Woodstock, Ont., Canada.

"I wish it were possible to tell you how much fun I had with the Pansies grown last year from your seed. The plants grew and they blossomed and blossomed and blossomed, and are still blooming today. Everyone said, "I never saw such pansies!' With the help of friends and neighbors I kept them traveling, and they took part in weddings, funerals, parties, receptions; they have said farewell to travelers, greeted babies, and always, everywhere, have given comfort and joy." MISS J. E. WATSON, 2521 Webster St., Berkeley, Calif.

"Kindly forward another packet of your Oregon Giant Pansy Seed and also send one to my friend who thought my Pansies last year were the finest, largest, and nost heautiful she had ever seen.

"My Pansies took the town for finest blooms-some 3 inches, some $3 \frac{1}{2}$. Sent them to Chamber of Commerce, Woman's Improvement Club, and to all lovers of flowers. I had a bed of about 300 or more, and they were simply magnificent." MRS. AUGUSTA. F. FLEMING, Box 267, Jackson, Calif. 
"I am taking time to write you about my pansies. I had about 20,000 transplanted, and the very favorable weather started them blooming unusually early. People are kind enough to say that they are the finest they have ever seen. It is also true as far as 1 am concerned. There is no doubt that your Seed comes nearest to producing less cull flowers of any Seed that I have tried."

CLYDE COFFIN, Windfall, Indiana.

(The reason for this is the careful selection of seed-plants year after year, no small or mediocre pansies being left in the garden to pollenize the others.)

"People are so familiar with the phrase 'Giant Pansies' that unless they see yours, they don't realize the real difference in Giants."

M. EMERSON MAIN, Westerly, R. I.

"I wish I could find words in the English vocabulary to describe the Pansy" blossoms from your seed. I never saw the like before! They are all very largelarger than anything I've seen anywhere around here, excepting my mother's, which came from the same source." MRS. GEORGE S. BIRCH, Vineland, N. J.

"I want to tell you what extreme pleasure the pansies gave me from your seed. I look first prize at our County Fair and so many of my friends told me they never saw such pansies. I have a bouquet in the house now which is late for this climate."

MISS MAUDE L. COLLVER, Simcoe, Ont., Canada.

“Last year I purchased 1,000 seeds of your Florists' Mixture and these Pansies are the admiration of the neighborhood." G. W. THACKER, Leroy, Michigan.

The Oregon Giants have been locally described as "Pansies so large that they have to be turned sideways to pass through the door!"

The following extract was printed in the "Commercial Appeal," a paper published in Memphis, Tennessee, and contains news of Arkansas, Mississippi, Alabama and Tennessee. It appeared on the editorial page and was a great surprise to Mrs. Murphy, who has made a name for herself and The Oregon Giants in four states.

"Macon, Miss., May 7. Macon has been made the City of Pansies by Mrs. Juanita Murphy, a nature-loving little woman who unconsciously fell into a business that has made her name famous in these parts, and has gladdened numberless homes in the city with a profusion of pansy bloom that is a riot of beauty and color. Because of an overabundance of flowers, friends suggested selling the surplus, which she tentatively did, almost at once finding herself smothered with orders for more. From a Northwestern Florist, Mrs. Merton G. Ellis, she had ordered seed of a special variety of giant pansies for the satisfaction of trying out a new variety, and these came up to and then far surpassed her hopes for their production, with a bewildering profusion of perfect blooms that were a marvel to every beholder because of their size. Orders for these pansies and the plants rolled in, and scarcely a lome can be passed where there is not a reminder of this unconsciously launched forist in the form of giant pansies of every tint and marking known to the breeders of the almost human-faced flowers." 
- 


\section{CULTURAL DIRECTIONS}

In most climates best results are obtained by planting Pansy Seed in the latter part of August or early September. If planted much earlier the seedlings will be ready to transplant before the Fall rains start and they are apt to die out.

Sow the seed thinly in flats and just barely cover the seed with sifted dirt. More people get a poor germination because of planting the seed too deep than any other cause except by letting the flats or seed-boxes dry out. They must be kept moist, but care must be taken even in this respect. Damping off may result from too much moisture, irregular, or other improper moisture conditions. Cover the seed-beds during the hot mid-day sunshine with a single sheet of newspaper or a cloth frame. Protect them also when there is apt to be a heavy storm. Seed should germinate in about a week in August. It takes a little longer later in the Fall.

Transplant when the seedlings have three or four leaves if the weather conditions are favorable. Better to let them become a little crowded than to transplant during a hot dry spell. They should be planted out in the open where they will get plenty of sunshine and where they will remain for spring blooming unless the winter is apt to be entirely too severe. In some places they will need the protection of cold frames but pansies will stand even some zero weather if protected by straw. Pansies that weather it through the winter out in the open will make the sturdiest plants, by far, and produce the largest, finest blooms.

Pansies want especially rich soil, plenty of sunshine, irrigation and shallow cultivation.

\section{GLADIOLI}

PANSY SEED PLANTED IN THE SPRING will begin blooming about May and will produce blooms all summer. With good care they will be at their best and give their largest blooms in the Fall.

Pansy Seed may be planted early in the Spring in cold frames, hot-beds, or in boxes indoors. When severe weather is over they may be planted outdoors.

Spring planting is especially desirable in climates too severe for the safe wintering over of plants from Fall-sown seed. Pansies are quite hardy and do well in nearly every climate. 


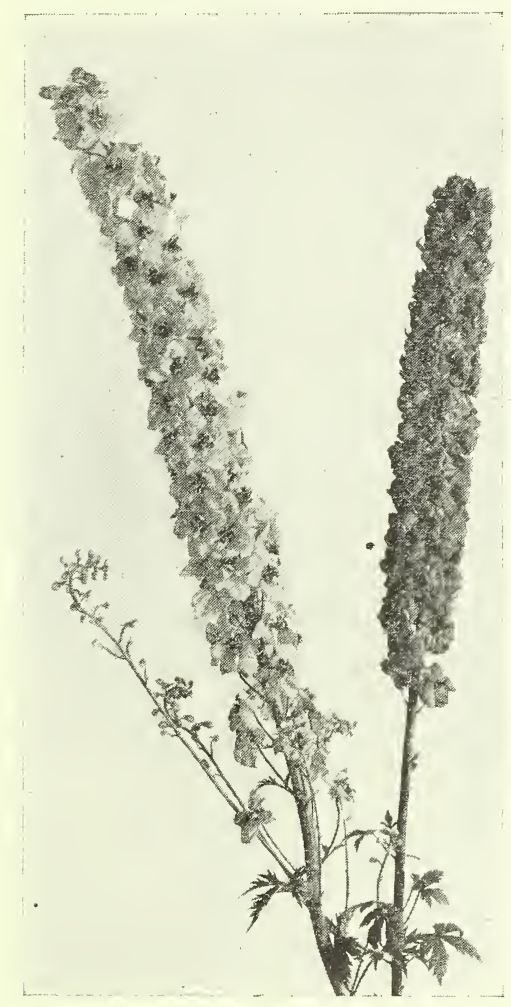

"WREXHAM" Strain: The famous "Wrexham" Delphiniums are the finest on the market today. We were fortunate in securing our start from the purest stock obtained from the originator of this fine strain.

"Wrexham" Delphiniums have splendidly shaped, tall spikes with wonderfully large individual flowers of rich, unusual shades.

Price: $\$ 1.00$ per packet.

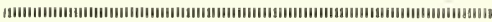

"HOODACRES" Strain: We can supply Delphinium Seed of the "Hoodacres" strain, which is also a well known and favorite variety.

Price: $\$ 1.00$ per packet (largesized packet).

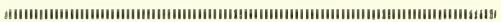

Order Delphinimu Seed early, as stock is limited.

Directions for Planting: It is best to plant Delphinium Seed in a green-house the middle of February or early in March. When the plants are of a fair size, transplant them out of doors, where they are to remain -about 3 feet apart.

Tcrms: Please send remittance with order to-

\section{MRS. MERTON G. ELLIS}




MRS. MARY S. BURKE (D)
Apricot Yellow

No. 1 No. 2 No. 3

No.

No. 5

No. 6

(100

MRS. P. W. SISSON (C)
MRS. RICHARD LOHRMAN (D) Creamy Shell Pink

MRS. WM. E. CLARK (Fischer) . Flesh Pink, Red Blotch

MRS. WM. KENT (D)

Tall, Vigorous Pink ..................................

MYSTIC (K) _............................ 10 Mottled Bright Rose Pink 100

NATALIE (K) Beautifully Ruffled Salmon... 100

PEARL OF THE DAWN (K) Beautifully Ruffled Pink 100

PINNACLE (Burbank) .................... 10 Tall Salmon

PINK LILY (K) .................. 10 Beautiful Soft Pink 100

PINK WONDER (Kemp) $\quad 10$ Large Light Pink 100

$\begin{array}{cr}\text { POLA NEGRI (D) } & 10 \\ \text { Apricot and Salmon } & 100\end{array}$

PRINCELY (Kemp) ......................................

PRIORITY (Bill)

PRINCE OF WALES (V.Z.) 10 Soft Light Salmon $\quad \ldots \quad 100$

PURPLE GLORY (K) ............................ 10 Ruffled Purplish Red 100

QUEEN OF THE NIGHT (D)............. 1

QUINTON (Kemp) _ _.......................... 1

RED FIRE (K) Reddest Red ......... 10

RICHARD DIENER (D) 10 Famous Pink 100

ROBT. J. KUNDERD (K)................ 10

ROSE ASH (D) 10 Ashes of Roses, Vigorous $\quad 100$

RUTH TAYLOR (D) ....................... 1

SEBESTA (K) 10

SELMA (Kemp) …_....... 1

SHEILA (C) ...._. 10

Light Salmon $\quad 100$

SIBYL (Bill)._...........................................

STARLIGHT (Bill) …_......................... 1

STANFORD (M) _..................................

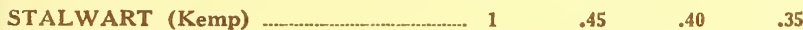

SULPHUR FRILLS (K) ..................... 11075

SULPHUR GLOW (K) ...................... 10

Ruffled Light Yellow 100

SUNSET (D)

Cerise Pink ................. 10

SWEET LAVENDER (C) .... 10 Early Lavender

$\begin{array}{lll}.65 & .55 & .45\end{array}$

$\begin{array}{rrrr}.65 & .55 & .45 & .35 \\ \cdots & \ldots . . & . .0 & 3.00\end{array}$

$1 / 2-9 / 4$

$1 / 2$-less

BULBLETS

$\begin{array}{rrrr}\cdots & .65 & .55 & .45 \\ \cdots-. . . & . . . & 4.50 & 3.5\end{array}$

$\begin{array}{rr}.35 & 20 \\ \ldots-. . & -. .\end{array}$

Per

$\begin{array}{llllll}100.00 & 90.00 & 80.00 & 70.00 & 60.00 & 50.00\end{array}$

$\begin{array}{rrrr}1.50 & 1.20 & .80 & .55 \\ 14.00 & 11.00 & 7.50 & 5.00\end{array}$

$\begin{array}{rr}.45 & .30 \\ 4.00 & 2.50\end{array}$

$.70 \quad .60$

$\begin{array}{llllll}.90 & .80 & .70 & .60 & .50 & .40\end{array}$

$\begin{array}{llllll}.60 & .50 & .40 & .30 & .25 & .15\end{array}$

$\begin{array}{llll}5.00 & 4.25 & 3.50 & 2.75\end{array}$

$\begin{array}{lllll}1.00 & .85 & .65 & .50\end{array}$

2.00

.35
3.00

.70

.60

5.00

.60

.45
3.75

5.00

3.75

.25
2.00

3.00

.25
1.50

1.50
...$--\quad .30$

.30
2.50

1.00

.75

.30

.20

2.00

1.50

.40
3.50

1.50

.30

1.00

.80
7.50

1.10

.75

6.50

1.25

1.00

.30

.20

1.00

2.00

.50
4.00

4.00

.50

.15

1.25

.15
1.00

.20

1.50

.50

.20

.15

1.00

.25
2.25

1.25

.25

.60
5.50

.55

4.50

.75

.15

$\begin{array}{lll}7.50 & 6.00 & 4.50\end{array}$

$\begin{array}{lll}.75 & .65 & .55\end{array}$

$.50 \quad .45$

$.80 \quad .65$

$7.50 \quad 6.01$

.50
4.50

....... ........

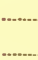

.35

.30

.25

.40
3.50

.30
2.50

.20

1.50

.15

100

1000

.75
6.00

$100 \quad 1.75$

$100 \quad 2.25$

$100 \quad .15$

1000

1.00

100
1000

.50
3.00

100

.60

$1000 \quad 5.00$

$100 \quad .5$

$100 \quad .25$

1000

2.00

100
1000

.15
1.00

100
1000

.20
1.75

1.00

$10 \quad .60$

100

1000

.15

100

1000

.40

10

2.00

$10 \quad .50$

100
$1000 \quad 9.90$

100

1000

1.00

$100 \quad 2.50$

100

1000

.15

10

100

4.00

10

100
1000

10

.25

.50

.40
3.00

$\begin{array}{lll}1.00 & .85 & .70\end{array}$

\begin{tabular}{rrrr}
1.00 & .85 & .65 \\
\hdashline- & -1.5 &
\end{tabular}

.65

4.00

.55

5.00

.45
4.00

THE ARISTOCRAT (Bill)

$3.50 \quad 3.25$

THOMAS A. EDISON (D)

Begonia Rose

UHLAN CHIEF (K)

VANITY (Bill)

VIRGINIA M. FISHER (D) ............... 10 Martha Washington Geranium … 100

WHITE DOVE (M)

WHITE PIGEON (K)

WHITE WONDER (Kemp) 


\section{SPECIAL BULBLET PRICES IN QUANTITY}

Pints and Quarts are by dry measure which is about a fourth larger than by liquid measure.

\begin{tabular}{|c|c|c|c|}
\hline Pint & Quart & Pint & Quart \\
\hline 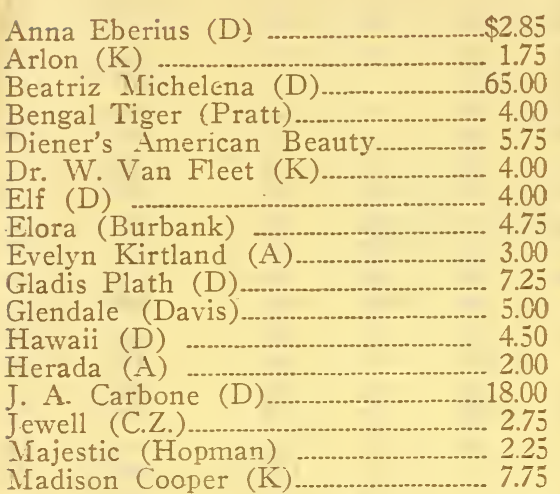 & $\begin{array}{r}\$ 5.50 \\
3.00 \\
125.00 \\
7.50 \\
11.00 \\
7.50 \\
7.50 \\
9.00 \\
5.50 \\
14.00 \\
9.50 \\
8.50 \\
3.50 \\
35.00 \\
5.00 \\
4.00 \\
15.00\end{array}$ & 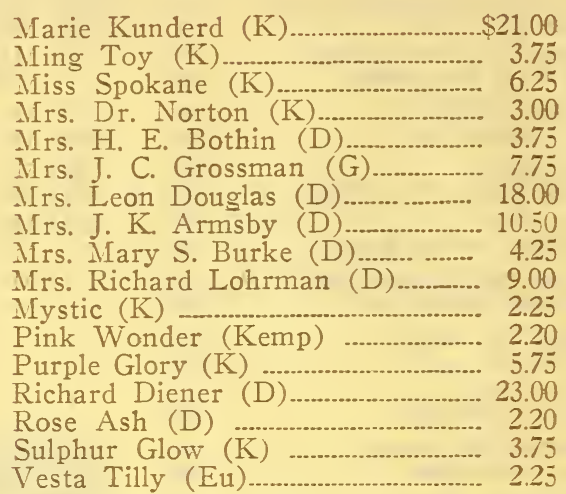 & $\begin{array}{r}\$ 40.00 \\
7.00 \\
12.00 \\
5.50 \\
7.00 \\
15.00 \\
35.00 \\
20.00 \\
8.00 \\
17.50 \\
4.00 \\
4.25 \\
11.00 \\
45.00 \\
4.25 \\
7.00 \\
4.00\end{array}$ \\
\hline
\end{tabular}
(K) Kunderd
Abbreviations (Introducer
(D) Diener (M) Metzner (C.Z.) C.
(A) Austin
cers, Originators or Places of Introduction):

TERMS - Cash, or 25\% down, and balance C.O.D. Where bulbs and bulblets are not otherwise listed, you may have 1 at 9 th of $10 ; 10$ at 9 th of $100 ; 100$ at 9 th of $1000 ; 5000$ at $41 / 2$ times $1000 ; 25$ at 100 rate; 250 at 1000 rate.
DISCOUNTS - On Cash Orders you may take $5 \%$ on $\$ 25.00$ or more; $10 \%$ on $\$ 50.00$ or more; $15 \%$ on $\$ 100.00$ or more.

SUBSTITUTIONS - If we are out of size ordered, we will give larger quantity of the same variety in the next smaller size we have in stock, unless you request us not to do so. We do not substitute one variety for another unless you so request.

ALL ORDERS are received subject to prior sale, and are shipped either postpaid or express prepaid. Orders of very large value are usually sent by express, for the express company insures safe delivery even against freezing.

The bulbs offered in the above list are of the finest quality and are grown on our famous bulb soil at Canby, Oregon, under the personal supervision of Merton G. Ellis. Our soil is a rich, sandy loam, just right for producing those fine mealy potatoes which are so sought after for baking, as distinguished from those watery potatoes which will never bake. Like the potatoes, our bulbs grown on this soil are plump and solid, and of finest texture and quality.

Last fall, we won the Blue Ribbon and Silver Cup at the Annual Flower Show at Silverton, Oregon, for the best Gladiolus exhibit, against the stiffest competition in the state. The flowers for this exhibit were taken from our field-grown stock and not especially grown for exhibition purposes. Hence, we are justly proud of the quality of our stock.

GUARANTEE - Our long list of satisfied customers and the phenomenal and rapid increase of our business, is our best guarantee. We exercise great care to send out healthy stock, true to name; should any prove untrue, we will replace three for one. We cannot, of course, guarantee the results you will obtain. However, as to the growing, we are glad to call your attention to the book, "Making Them Grow," by Merton G. Ellis. Many say it is worth hundreds of dollars to the grower desirous of quickly increasing his stock of the new and higher priced varieties. Price, $\$ 3.50$ per copy, postpaid; or free with orders of $\$ 50.00$ or more.

BANK REFERENCE - Canby State Bank, Canby, Oregon .

Watch our ads in the Official Bulletin and The Flower Grower, for special offers of collections, and some of our new originations.

\section{THE MERTON G. ELLIS TEST GARDENS CANBY, OREGON}

